Ibragim Khasanov, “Rus Basınında Arap Baharı,” Üsküdar Üniversitesi Sosyal Bilimler Dergisi, say1: 10, (Mayıs 2020): 93-128,

http://doi.org/10.32739/uskudarsbd.6.10.70

\title{
Rus Basınında Arap Baharı
}

Arab Spring in the Russian Press

Ibragim KHASANOV ${ }^{*}$

\section{$\ddot{0} z$}

Arap Baharı olarak adlandırılan süreç, Tunus'ta 26 yaşındaki üniversite mezunu olan Muhammed Bouazizi'nin 17 Aralik 2010'da kendisini ateşe vermesinin ardindan başlamıştır. Tunus'ta başlayan gösteriler daha sonra, Mısır, Yemen, Bahreyn, Libya ve Suriye başta olmak üzere diğer bazı Kuzey Afrika ve Ortadoğu ülkelerine yayılmıştır. Rusya Federasyonu Tunus, Misir, Yemen, Bahreyn ve Libya gibi Arap Baharinin yaşandiğı ülkelere yönelik Batı devletlerinin çizgisine yakın bir tutum sergilemiştir. Suriye'de ise hükümetin yanında yer alarak krize askeri olarak müdahil olmuştur. Rus basınında Arap Baharı olayları, devletin resmi çizgisinin aksine daha geniş ölçekli bir yaklaşıma tabi tutulmuştur. Makalede Rus basınının Arap Baharı olaylarına yaklaşımı irdelenmiştir.

Anahtar Kelimeler: Arap Baharı, Rusya Federasyonu, Rus basını, Ortadoğu, Suriye.

\section{Abstract}

The Arab Spring started in Tunisia after Muhammad Bouazizi, a 26-year-old university graduate, set himself on fire on December 17, 2010. The demonstrations started in Tunisia later spread to other North African and Middle Eastern countries, including Egypt, Yemen, Bahrain, Libya, and Syria. The political stand of Russia concerning the countries experiencing the Arab Spring such as Tunisia, Egypt, Yemen,

\section{Özgün Araştırma Makalesi (Original Research Article)}

Geliş Tarihi: 08.03.2020

Kabul Tarihi: 19.04.2020

${ }^{(*)}$ Giresun Üniversitesi Sosyal Bilimler Enstitüsü Uluslararası İlişkiler Anabilim Dalı Yüksek Lisans Öğrencisi, khasanov.ibragim@yandex.ru

ORCID ID: https://orcid.org/0000-0003-1544-3739 


\section{Ibragim KHASANOV}

Bahrain, and Libya, has been close to the line of Western states. In Syria, Russia was involved in the crisis militarily by taking the side of the Syrian government. Arab Spring events in the Russian press have been subject to a larger-scale approach, contrary to the state's official position. In this article, the approach of the Russian press to Arab Spring events is examined.

Keywords: Arab Spring, The Russian Federation, Russian press, Middle East, Syria.

\section{Giriş}

Rusya Federasyonu'nun Arap Dünyası ile ilişkileri uluslararası politikada Soğuk Savaş düzeninin hâkim olduğu XX. yüzyılda en üst seviyeye ulaşmıştır. Bu dönemde Sovyetler Birliği, bilhassa Suriye, Irak

Üsküdar University Journal of Social Sciences, 2020; issue: 10 , 93-128 ve Güney Yemen'le (Yemen Demokratik Halk Cumhuriyeti) yakın siyasi, askeri ve ekonomik ilişkiler tesis etmiştir. İki kutuplu sistemin sona ermesini takiben Ortadoğu bölgesi uluslararası politikada önemli yerini muhafaza etmeye devam etmiş olsa da Sovyetler Birliğinnin yerini alan Rusya Federasyonu'nun bu bölge ile ilişkileri 1991 öncesi seviyeye ulaşamamıştır. 2000'lıyıllara gelindiğinde ise Rusya'nın iç ve dış siyasetinde vuku bulan bir dizi mühim değişimler ve uluslararası konjonktürün de etkisiyle birlikte Rusya ile Arap devletleri arasında ilişkiler yoğunluk kazanmaya başlamıştır. Rusya bu dönemde, Libya, Mısır, Suriye, Irak ve Körfez ülkeleriyle önemli ticari, ekonomik ve askeri iş birliği anlaşmaları yapmıştır.

2010 yılının aralık ayında Tunus'ta başlayan ve kısa süre içinde diğer Arap devletlerine yayılan hükümet-karşıtı gösteriler, uzmanlar tarafından Arap Baharı olarak adlandırılmıştır. Bu olaylar, Arap Dünyası'nda ve Ortadoğu bölgesinin genelinde mühim sonuçlar doğurmakla kalmamış, aynı zamanda bölge ve bölge-dışı aktörlerin Ortadoğu politikalarını revize etmeye yöneltmiştir. Bu aktörlerden biri de şüphesiz Rusya Federasyonu olmuştur. Ortadoğu'da birçok ülkeyi etkisi altına alan hükümet-karşıtı gösteriler/ayaklanmalar için her ne kadar Arap Baharı adı altında ortak 
bir tabir kullanılmışsa da bu olayların mahiyeti gelişmelerin yaşandığı ülkelerin spesifik özellikleri, dış aktörlerin yaklaşımları gibi faktörlere bağlı olarak farklılık göstermektedir. Bu çerçevede Tunus, Mısır, Libya, Yemen, Bahreyn ve Suriye'deki Arap Baharı'na bağlı olarak yaşanan gelişmelere Rusya’nın yaklaşımı da bahsi geçen faktörlere göre farklı şekiller almıştır. Bu kapsamda, Rusya'nın Arap Baharı sürecindeki Ortadoğu politikasının bölgesel düzeyde siyasi, askeri ve ekonomik çıkarlarını korumak, küresel güçler düzeyinde Ortadoğu'daki konumunu muhafaza etmek ve Arap Baharı́nın kendi iç siyasi toplumsal dinamikleri üzerinde yaratabileceği olumsuz etkilerin önüne geçmek hedefleri doğrultusunda şekillenmiş olduğu ifade edilebilir.

Arap Baharı́na bağlı olaylar Tunus'ta aniden ortaya çıkmış, hızla gelişmiş, birçok ülkeyi etkisi altına almış ve bölgesel ve uluslararası düzeyde geniş yankı bulmuştur. Bu hususta, Rus basınında bahsi geçen olaylara geniş yer verildiği belirtilmelidir. Rus basınında Arap Baharı süreci siyaset, ekonomi, dış politika ve din gibi birçok düzlemde geniş bir analize tabi tutulmuştur. Çalışmada, Rusya'nın devlet düzeyinde Arap Baharı'na yaklaşımı, Arap Baharı için önemi haiz olan Tunus, Mısır, Libya, Yemen ve Suriye'deki gelişmelere Rus basınının önde gelen gazeteleri olan Vedomosti, Kommersant, Rossiyskaya gazeta ve Gazeta.ru'nun yaklaşımları incelenecektir.

\section{Rusya Federasyonu'nun Arap Baharı'na Yaklaşımı}

Arap Baharı olarak adlandırılan süreç, Tunus'ta 26 yaşındaki üniversite mezunu olan ama iş bulamadığı için seyyar satıcılık yapan Muhammed Bouazizi'nin 17 Aralık 2010'da kendisini ateşe vermesinin ardından başlamıştır. 24 Aralık'ta gösterilerde ilk defa polisin ateş açması sonucu 18 yaşında bir gencin öldürülmesi ile de olaylar patlama noktasına gelmiştir. Tüm ülkede binlerce kişinin katıldığı gösteriler, giderek işsizlik ve ekonomiye olan itirazlardan rejim karşıtlı̆̆ına dönüşmüştür. Daha sonra, 


\section{Ibragim KHASANOV}

gösteriler Mısır, Yemen, Bahreyn, Libya ve Suriye başta olmak üzere diğer bazı Kuzey Afrika ve Ortadoğu ülkelerine yayılmıştır. Tunus ve Mısır'da gösterilerin başladığı ilk zamanlarda, bölgede yaşananlarla ilgili farklı görüşler ifade edilmiştir. Gösteriler, ülkeler arasında ayrım yapılmaksızın, büyük bir "Arap Uyanışı", büyük şehirlerdeki kentli ve kozmopolitan genç insanların ayaklanması ve seküler, seçkinci otoriter düzenlere karşı Müslüman halkın demokratik başkaldırısı olarak değerlendirilmiştir ${ }^{1}$

Arap Baharı'yla birlikte Ortadoğu ülkelerinde ortaya çıkan dinamik süreç, bir yandan bu ülkelerin içyapılarında köklü değişikliklerin yaşanmasına olanak sağlarken diğer yandan da Rusya Federasyonu'nun Arap devletleriyle münasebetlerinde çizgisinin/stratejisinin gözden

Üsküdar University Journal of Social Sciences, 2020; issue: 10 , 93-128 geçirilmesine ve bölgedeki jeopolitik konumuna önemli etkilerde bulunmuştur. Rusya Federasyonu'nun Arap dünyası üzerinde nüfuzu, Soğuk Savaş döneminde Sovyetler Birliği'nin dünyanın muhtelif bölgelerinde olduğu gibi Ortadoğu ve Afrika'da Avrupalı devletlere karşı yürütülen ulusal bağımsızlık mücadelelerini desteklemesi ile mümkün olmuştur ve zirveye ulaşmıştır. XX. yüzyılın 70'li yıllarında hemen hemen bütün Arap devletleri Sovyetler Birliği ile yakın siyasi, iktisadi, askeri ve kültürel iş birliği içinde olmuşlardır 1991'de Sovyetler Birliği'nin dağılması ve Ortadoğu'daki sosyalist rejimlerin çökmeye başlaması, Rusya ile Arap devletleri arasındaki münasebetlerin ideolojik temelden küreselleşme sürecinin ruhuna uygun pragmatizme dayalı ekonomik ve siyasi iş birliği düzlemine geçmesine yol açmıştır. ${ }^{2}$

\footnotetext{
${ }^{1}$ Kemal Çiftçi, “Ulus-Devletlerden Kozmopolitan Küreselleşmeye Uluslararası Siyaseti Yeniden İnşa Etmek: Arap Baharı Örneği”, Karadeniz Sosyal Bilimler Dergisi 7, sayı: 13, (2015): 193-194.

${ }^{2}$ Farit Giniyatov, "Sobıtiya arabskoy vesnı i ih vliyaniye na geopolitiçeskoye polojeniye Rossii v blijnevostoçnom regione," Vestnik ekonomiki prava i sotsiologii, sayı: 2, (2013): 134.
} 


\section{Rus Basınında Arap Baharı}

Sovyetler Birliği’nin dağılmasından sonra Rus diş politikasında Ortadoğu nezdinde ortaya çıkan sorun, Soğuk Savaş döneminde Rusya'nın iki önemli stratejik müttefiki olan Irak ve Suriye ile ilgili olmuştur. Rusya Federasyonu, Irak'ın Kuveyt'i işgali sonucunda Birleşmiş Milletler Güvenlik Konseyi'nde (BMGK) bu ülkeye yönelik yaptırım uygulanması kararını desteklemiştir. Fakat gerek bu ülkedeki ekonomik çıkarları gerekse de ihtilafın barışçıl yöntemlerle bir an önce çözüme kavuşturulmasını istemesi, Rusya'yı daha sonra bu yaptırımların kaldırılması gerektiğini savunmaya yöneltmiştir. Sonuç olarak, Rusya Federasyonu'nun bu yöndeki diplomatik girişimleri olumlu neticeler verememiştir ve Rusya, Sovyetlerin izlediği Irak siyasetinden vazgeçmek zorunda kalmıştır. Diğer taraftan; yeni Rusya Federasyonu, ABD ile Avrupa ülkeleri tarafindan uluslararası terörizme destek veren ülke ilan edilen, ekonomik yaptırımlar uygulanan ve komşuları Türkiye, Ürdün ve Irak'la sorunlar yaşayan bir Suriye'yle karşı karşıya kalmıştır. Bu şartlar altında, bu devlete yönelik aktif siyaset izleyemeyen Rusya'nın durumu, Suriye’nin Irak’a karşı BMGK kararıyla oluşturulan koalisyon kuvvetlerine katılmasıyla değişmiştir. Batı́nın Suriye'ye yönelik evvelki suçlamaları ve yaptırımları kaldırması neticesinde, Rusya 1994'ten itibaren bu ülkeyle yakın münasebetler tesis etmiş ve iki ülke arasında askeri-teknik iş birliği tekrar başlamıştır. ${ }^{3}$ Bununla birlikte belirtilmesi gereken mühim bir husus, 1990’lı yıllarda Rusya'nın Ortadoğu ülkeleriyle ve bilhassa Suriye ile münasebetlerinin mahiyetinin dünyada vuku bulan jeopolitik değişikliklere, Rus dış politikasının ilk etapta izlediği Atlantikçi çizgiye ve yeniden diplomatik ilişkiler tesis ettiği İsrail faktörlerine bağlı olduğudur.

Sovyet/Rus silah ithalatçısı Libya'ya yönelik olarak, Rusya Federasyonu 1992'de ABD'nin BMGK'ye sunduğu yaptırım kararına destek vermiş ve tek taraflı olarak bu ülkeyle askeri-teknik, petrol arama ve diğer sahalarda

\footnotetext{
${ }^{3}$ Marina Sapronova, "Rossiysko-arabskoye sotrudniçestvo do i posle arapbskoy vesnı", Vestnik MGIMO Universiteta 3, sayı: 36, (2014): 28.
} 


\section{Ibragim KHASANOV}

münasebetlerini durdurma kararı almıştır. 1990'lı yılların başlarında, Filistin meselesinin çözümü noktasında daha esnek ve daha az İsrail karşıtı bir yaklaşımın benimsenmesine karşın Yaser Arafat liderliğindeki Filistin Kurtuluş Örgütü’nün (FKÖ) Kuveyt'in işgali meselesinde Saddam Hüseyin'in tarafinda yer alması, uluslararası alanda FKÖ’ye verilen desteğin azalmasına ve Filistin meselesinin Sovyet sonrasında Rus dış politikasında arka plana atılmasına neden olmuştur. 1996'da Evgeniy Primakov'un Dışişleri Bakanı olarak atanmasıyla konu tekrar gündeme gelmiş ve birtakım girişimlerde bulunulmuşsa da bunlardan etkin bir netice elde edilememiştir. ${ }^{4}$

1990'lı yılların ikinci yarısından itibaren, Rusya Federasyonu ile Arap devletleri arasındaki münasebetler "durgunluk" döneminden çıııp

Üsküdar University Journal of Social Sciences, 2020; issue: 10 , 93-128 öncelikle iktisadi çıkarların tayin etmeye başladığı karşılıklı kazanca dayalı ticari ve ekonomik iş birliği düzleminde şekillenmeye başlamıştır. $\mathrm{Bu}$ doğrultuda, taraflar arasında iş birliğinin hukuki temellerini teşkil edecek olan bir dizi anlaşmalar imzalanmıştır. Böylece, Rus şirketlerinin Mısır, Yemen, Irak ve Lübnan gibi Arap devletlerinin pazarlarına girmelerinin önü açılmıştır. Rusya Federasyonu, Soğuk Savaş dönemindeki müttefikleri, ortaklarıyla olduğu gibi, bu dönemde sahip oldukları finansal kaynaklarla öne çıkan Körfez ülkeleriyle de ilişkiler tesis etmeye yönelmiştir. Rusya'nın içinde bulunduğu siyasi ve iktisadi durumu ve ayrıca Suudi Arabistan başta olmak üzere diğer Körfez ülkelerinin Çeçen ayrılıkçılara destek vermeleri, bahsi geçen dönemde taraflar arasındaki münasebetlerin gelişmesini engelleyen hususların başında gelmiştir. ${ }^{5}$

Bütün bunlara rağmen 2000’li yıllarda Rusya Federasyonu ile Arap devletleri arasındaki münasebetler olumlu bir seyir izlemeye başlamış ve belirli bir seviyeye gelebilmiştir. Rusya'nın bölgede iktisadi varlığı artmış, Sovyetler Birliği’nin eski müttefiklerinin yanı sıra Suudi Arabistan ve Ürdün

\footnotetext{
${ }^{4}$ A.g.e., 29.

${ }^{5}$ Sapronova, "Rossiysko-arabskoye sotrudniçestvo do i posle arapbskoy vesnı", 30.
} 


\section{Rus Basınında Arap Baharı}

gibi devletlerle de iktisadi ve askeri iş birliği tesis edilmiştir. ${ }^{6}$ Bu çerçevede, Cezayir ve Suriye'nin Soğuk Savaş döneminden kalan borçlarının önemli bir bölümü silinmiş olup, karşılığında da bu devletler Rusya'dan silah ithal edeceklerine dair anlaşmalar imzalamıştır. Rus şirketleri Suudi Arabistan başta olmak üzere diğer Körfez ülkelerinin petrol ve doğal gaz sahalarında çalışmaya başlamış ve Rusya kendi roketleriyle Arap uydularının uzaya ulaşmasını sağlamıştır.?

Ancak Ortadoğu'da Arap Baharı olarak adlandırılan olayların baş göstermesi, Rusya'nın bölgeye yönelik siyasetini doğrudan etkilemiş ve Rusya’yı zor durumda bırakmıştır. Bu dönemde Ortadoğu'da patlak veren olayların, başlangıçta Moskova'nın bölgedeki varlığına zarar vermeyeceği, hatta bölgenin kısa bir süre istikrarsız kalmasının Rusya’nın işine yarayacağı düşünülmüştür. Zira Ortadoğu'nun daha fazla istikrarsızlaşması ve buna paralel olarak enerji kaynaklarının fiyatlarının artması, Rusya'nın kısa vadede işine yarayan gelişmeler olmuştur. Ayrıca bu husus, bir kez daha, enerji alanında Rusya’ya alternatif olarak gösterilen Ortadoğu ülkelerinin güvenilirliğinin sorgulanmasına neden olmuştur. Ancak Arap Baharı'nın gittikçe genişlemesi ve uzaması, Rusya'nın Ortadoğu politikasına da zarar vermiştir. ${ }^{8}$

Arap Baharı'na bağlı olayların bir bakıma aniden vuku bulması ve kısa sürede Arap dünyasında yayılmaya başlaması diğer pek çok ülke gibi Rusya Federasyonu'nu da hazırlıksız yakalamıştır. Rusya Federasyonu Dışişleri Bakanı S. Lavrov, 2011'de bir Rus televizyon kanalına verdiği röportajda, Arap dünyasında yaşanan olayları "beklenen ani olaylar” olarak nitelendirmiştir. Lavrov’a göre, olayların yaşanması bekleniyordu çünkü bölgede uzun zamandır biriken sosyo-ekonomik sorunlara devletlerin

\footnotetext{
${ }^{6}$ Yusef Nassasra, "Strategiçeskiye prioritetı blijnevostoçnoy politiki Rossii v period posle arabskoy vesnı,” Privoljskiy nauçnıy vestnik 12-1, sayı: 52, (2015): 129.

${ }^{7}$ Sapronova, "Rossiysko-arabskoye sotrudniçestvo do i posle arapbskoy vesnı”, 33.

${ }^{8}$ İlyas Kemaloğlu, Rusya’nın Ortadoğu Politikası, (Ankara: ORSAM 2012), 14.
}

Üsküdar

Üniversitesi

Sosyal Bilimler

Dergisi, 2020;

sayl: 10 ,

93-128 


\section{Ibragim KHASANOV}

yetkilileri gerekli ilgiyi göstermiyordu. Diğer taraftan, Bakana göre, Arap Baharı beklenmedikti çünkü çok hızlı bir şekilde ortaya çıkmıştı ve yine aynı hızla birkaç devlete yayılmıştı. ${ }^{9}$

Alman Uluslararası Siyaset ve Güvenlik Enstitüsü uzmanlarından Margarete Klein, Rusya’nın ülkeler bazında Arap Baharı'na yaklaşımında üç tür tepkiden bahsetmektedir. Uzman, Rusya Federasyonu'nun Tunus, Misır, Yemen ve Bahreyn'de meydana gelen olaylara "izleyici" olarak yaklaştığını/tepki verdiğini öne sürmektedir. Bununla beraber, olayların şiddetinin arttığı ve krize yabancı devletlerin müdahil olduğu Libya örneğinde ise Rusya'nın Kaddafi'ye sempati duymasına rağmen "tarafsız" kaldığını belirtmektedir. Suriye meselesinde de Batı ile ilişkilerinin gerginleşmesini göze alarak Rusya'nın doğrudan hükümetin yanında yer

Üsküdar University Journal of Social Sciences, 2020; issue: 10 , 93-128 aldığı Klein tarafından ifade edilmektedir. ${ }^{10}$

Uzman tarafından yapılan bu tasnifin önemli oranda Rusya'nın Arap Baharı́na yaklaşımını yansıttığı kabul edilebilir. Rusya, Tunus'ta Aralık 2010'da başlayan ve 2011'de dönemin Cumhurbaşkanı'nın ülkeden kaçmasıyla sonuçlanan olaylara, ölçülü ve sağduyuyla yaklaşmıştır. Dışişleri Bakanlığı tarafından, Rusya’nın olaylardan tedirginlik duyduğu ifade edilmiş ve ülkede istikrarın yeniden tesis edilmesi için taraflara sorunu şiddete başvurmadan demokratik yollardan çözmeleri çağrısında bulunulmuştur. ${ }^{11}$ Daha sonra ülkede düzenlenen ve 1 lımlı İslamcı partinin kazandığı parlamento seçimleri, Rusya tarafından olumlu karşılanmıştır.

\footnotetext{
${ }^{9}$ RF Dışişleri Bakanlığı, “RF Dışişleri Bakanı S.Lavrov’un Kanal 3’te V.Solovyev’a verdiği röportaj”” erişim 18 Aralık 2018, http://www.mid.ru/foreign_policy/news/-/asset_ publisher/cKNonkJE02Bw/content/id/215526

${ }^{10}$ Aleksandr İlinıh, "Arabskaya vesna i rossiyskaya politika na Arabskom Vostoke v novıh usloviyah," İstoriko-pedagogiçeskiye çteniya 17, (2013): 104.

${ }^{11}$ RF Dışişleri Bakanlığı, "RF Dışişleri Bakanlığı Sözcüsü A.K.Lukaşeviç’in Tunus'taki olaylara dair açıklaması”, erişim 18 Aralık 2018, http://www.mid.ru/ru/press_service/ spokesman/official_statement/-/asset_publisher/t2GCdmD8RNIr/content/ $\mathrm{id} / 222358$
} 


\section{Rus Basınında Arap Baharı}

Mısır'ın Arap dünyasındaki konumu, en kalabalık Arap devleti olması, askerî açıdan önde gelen Ortadoğu ülkesi olması, Amerikan yardımlarından en fazla yararlanan ülkelerin başında gelmesi ve Filistin meselesindeki arabuluculuk rolü, bu ülkeyi Rusya nezdinde önemli kılmaktadır. Mısır'da Arap Baharı çerçevesinde yaşanan olaylarda Rusya Federasyonu taraflara eşit mesafede yaklaşarak dengeli bir tutum sergilemiştir. Dışişleri Bakanlığı Tunus için yaptığı açıklamanın bir benzerini Mısır için de yapmıştır. ${ }^{12}$ Ülkede yönetimin değişmesini takiben Rusya, Hüsnü Mübarek’in idam edilmesine karşı olduğunu açıkça belirtmiştir. Daha sonra ılımlı İslamcıların zaferle ayrıldıkları parlamento ve cumhurbaşkanlığı seçimlerinin sonuçlarını kabul ettiğini duyurmuştur.

Bahreyn'deki olaylar karşısında Rusya tarafsızlığını korumuş ve Manama yönetiminin çağrısı üzerine ülkeye Suudi Arabistan ve Birleşik Arap Emirlikleri (BAE) tarafindan askeri birliklerin gönderilmesine karşı çıkmamıştır/sessiz kalmıştır. Rusya Yemen'deki olaylar karşısında tarafsızlığını korumakla birlikte dönemin Cumhurbaşkanı Salih'in görevini bırakması karşılığında can güvenliğinin sağlanması gerektiğini savunmuştur. Ayrıca Suudi Arabistan önderliğindeki Körfez Arap Ülkeleri İşbirliği Konseyi (KİK) ülkelerinin iktidar ile muhalefet arasında arabuluculuk yapma tekliflerini desteklemiştir. 23 Kasım 2011'de Riyad'da Cumhurbaşkanı Salih’in görevini yardımcısı Hadi'ye bırakacağına dair anlaşmanın imzalanması merasiminde Rusya Federasyonu Yemen Büyükelçisi hazır bulunmuştur. ${ }^{13}$

${ }^{12}$ RF Dışişleri Bakanlığı, "RF Dışişleri Bakanlığı Sözcüsü A.K.Lukaşeviç’in Mısır'daki olaylara dair açıklaması”, erişim 18 Aralık 2018, https://www.mid.ru/ru/press_service/ spokesman/official_statement/-/asset_publisher/t2GCdmD8RNIr/content/ $\mathrm{id} / 219002$

13 Aleksandr Demçenko, “«Arabskaya vesna» i politika Rossii v blijnevostoçnom regione,” Perspektivy, (2012), erişim 18 Aralık 2018, http:/ /www.perspektivy.info/rus/ desk/arabskaja_vesna_i_politika_rossii_v_blizhnevostochnom_regione_2012-09-15. htm 


\section{Ibragim KHASANOV}

Libya'daki olaylarda Rusya Federasyonu'nun tutumu, Arap Baharı'nın yaşandığı diğer ülkelerden farklılık göstermiştir. Olaylar patlak verdiğinde Moskova'dan gelen açıklamalar, Tunus ve Mısır için yapılanlarla paralellik arz etmiştir. Fakat krizin ilerlemesi ve ülkedeki şiddet olaylarının artması üzerine Rusya, Libya yönetimini sivil halka karşı kuvvet kullanmakla suçlamıştır. 26 Şubat 2011 tarihli 1970 numaralı Libya'ya silah ambargosu uygulanmasını öngören BMGK kararını desteklemiştir. Bununla birlikte sonrasında NATO’nun Libya'ya müdahalesi için kullanacak olduğu BMGK 1973 numaralı kararın oylamasında çekimser kalmıştır. ${ }^{14}$ Rusya her ne kadar bu müdahaleyi eleştirmeye/kınamaya devam ediyor olsa da kararın kabul edilmemesi için BMGK'de veto hakkını kullanmamıştır.

Üsküdar University Journal of Social Sciences, 2020; issue: 10 , 93-128

Suriye'deki iç savaşta Rusya Federasyonu, Batı ile bazı Arap devletlerini karşısına alarak merkezi yönetimin yanında yer aldığını ortaya koymuştur. $\mathrm{Bu}$ çerçevede, BMGK nezdinde Suriye hükümetini kınayan karar tasarılarını veto etmiştir. Bugün gelinen nokta itibarıyla, Suriye'deki kriz halen nihai bir çözüme kavuşturulamamışken Rusya ihtilafın başlangıcındaki tutumunu sürdürmeye devam etmektedir.

Rusya Federasyonu'nun Arap Baharı olarak adlandırılan sürece yönelik politikalarını yerel, bölgesel ve küresel düzeylerde ele alınabilecek olan üç temel faktöre bağlı olarak şekillendiğini ifade etmek mümkündür. ${ }^{15}$ Rusya'nın Arap Baharı siyasetinin oluşmasında ülkeler bazında farklılık arz eden bölgesel çıkarları önemli rol oynamıştır. Nitekim sınırlı ilişkilere sahip olduğu Tunus, Mısır, Bahreyn ve Yemen'deki hadiseler sürecinde daha geri planda kalmayı tercih etmiş olan Moskova, olayların Libya ve Suriye gibi çok daha önemli siyasi, askeri ve iktisadi ilişkilere sahip olduğu ülkelere yayılmasından sonra aktif bir siyaset izlemeye başlamıştır.

14 Demçenko, “«Arabskaya vesna» i politika Rossii v blijnevostoçnom regione," Perspektivy.

${ }^{15}$ Emre Erşen, “Rusya'nın Arap Baharı Politikası,” Arap Baharı Üzerine Değerlendirmeler içinde, ed. Armağan Gözkaman ve Perihan Paksoy, (Ankara: Detay, 2014), 117. 


\section{Rus Basınında Arap Baharı}

Daha evvel de belirtildiği üzere, Arap Baharı sürecinin ilk aşamasında Rusya Federasyonu olaylara sınırlı tepkiler vererek uzaktan izlemekle yetinmiştir. Rusya'nın Arap Baharı politikası için ilk dönüm noktası olarak nitelendirilebilecek hadise ise Libya'ya yayılması olmuştur. Arap Baharı'ndan etkilenen diğer ülkelerin aksine, Rusya Federasyonu ile Libya arasında önemi yadsınamayacak bir ticari-ekonomik iş birliği mevcuttu. 2008'de Rusya, Libya’nın Sovyetler Birliğine olan yaklaşık 4,5 milyar dolarlık borcunu silme kararı almıştır. Buna mukabil, Rusya Libya'dan kendi petrol ve silah şirketleri lehine önemli kazanımlar elde etmiştir. $\mathrm{Bu}$ durum, Rusya'nın Libya konusunda daha hassas bir yaklaşım sergilemesini gerekli kılmıştır. ${ }^{16}$

Rusya’nın Arap Baharı politikasında en önemli dönüşüm, şüphesiz, Suriye kriziyle birlikte yaşanmıştır. Rusya, bu ülkedeki ihtilafta doğrudan taraf tutmaya başlamış ve 2015 yılı itibarıyla sürece askeri olarak müdahil olmuştur. Suriye'nin, Rusya için Ortadoğu'da Sovyet döneminden itibaren en önemli ortak olarak öne çıkmasında bazı etkenler rol oynamıştır. 20052010 yılları arasında Rusya Suriye'ye 2,5 milyar dolar değerinde silah ihraç etmiştir. Yine bu dönemde Suriye Sovyetler Birliği döneminden kalan borcunu taksitle ödemeye başlamıştır. Rusya'nın Suriye'den ithal ettiği tekstil ürünlerinden aldığı gümrük vergisinde indirime gitmesi gibi bazı adımlar, 2010 yılına gelindiğinde iki ülke arasındaki ticaret hacminin artmasını sağlamıştır. Askeri teknolojiler ve enerji alanlarında iş birliği olumlu seyir izlemiştir. ${ }^{17}$ Rusya, ayrıca, BM gibi uluslararası platformlarda Suriye'ye siyasi desteğini esirgememiştir. Siyasi iş birliğinin bir diğer tezahürü de 2008'de meydana gelen Rusya-Gürcistan savaşında kendini göstermiştir. Suriye, bu savaşta Moskova'nın yanında yer alan dünyadaki az sayıda devletten biri olmuştur. Rusya’nın bölgesel çıkarları açısından esas olarak belirtilmesi gereken husus, Suriye'deki Tartus limanı ile buradaki

\footnotetext{
${ }^{16}$ Erşen, “Rusya’nın Arap Baharı Politikası,” 119.

${ }^{17}$ Kemaloğlu, Rusya'nın Ortadoğu Politikası 13.
} 


\section{Ibragim KHASANOV}

Rus askeri varlığıdır. 1971'den itibaren burada faaliyette olan ikmal ve bakım üssü, Suriye'yi Rusya Federasyonu için bölgedeki en mühim dayanağı haline getirmiştir. Suriye, Rusya'nın Ortadoğu ve Akdeniz'deki çıkarlarının merkezi olmuştur. ${ }^{18}$

1990’lı yılların ortalarında, dış politikasında yaşadığı kırılma ile birlikte, Rusya Federasyonu uluslararası alanda kendini küresel bir güç olarak kabul ettirme siyasetine yönelmiştir. Bu siyasi çizginin arkasında 1996-1998 yılları arasında Dışişleri Bakanı, 1998-1999'da ise Başkanlık görevini yürütmüş olan Evgeniy Primakov'un olduğu vurgulanmalıdır. Daha sonra Primakov Doktrini olarak adlandırılacak olan ve Rusya'nın çok kutupluluk ekseninde pragmatik, gerçekçi bir dış politika izlemesi,

Üsküdar University Journal of Social Sciences, 2020; issue: 10 , 93-128 $\mathrm{ABD}$ hegemonyasını dengelemek için yüzünü Doğu'ya çevirmesi gerektiği yönündeki ilkeler bütünü Rusya Federasyonu dış politikasının temel çerçevesini oluşturmuştur. ${ }^{19}$ Bu bağlamda Primakov Doktrini Doğu ve Asya ülkeleri kapsamında sadece Çin Halk Cumhuriyeti ve Hindistan gibi devletlerle değil, Ortadoğu özelinde Türkiye ve İran gibi bölgesel güçler başta olmak üzere ABD'nin tek taraflı politikalarından rahatsızlık duyan aktörlerle de ilişkiler geliştirmeyi öngörmüştür. ${ }^{20} \mathrm{Bu}$ çizgi, Vladimir Putin'in iktidara gelmesiyle belirginlik kazanmıştır. 2008 Rusya-Gürcistan Savaşı, Soğuk Savaş sonrasında ortaya çıkan, ABD’nin tek süper güç olduğu uluslararası sisteme karşı Rusya'nın ilk fiili meydan okumasıdır. Bu savaş, Rusya'nın daha aktif ve cüretkâr bir dış politika izlemeye başladığının da en mühim tezahürü olmuştur. Bu bağlamda Rusya, Suriye krizini Batı/ $\mathrm{ABD}$ ile olan küresel mücadelesinin bir parçası olarak kabul etmiştir. Suriye hükümetinin devrilmesinin (müttefikini koruyamadı̆̆ı için)

\footnotetext{
${ }^{18}$ Erşen, “Rusya’nın Arap Baharı Politikası,” 121.

${ }^{19}$ Dmitriy Novikov, "Ritsar rossiyskogo realizma," erişim 21 Nisan 2020, https://www. globalaffairs.ru/articles/ryczar-rossijskogo-realizma/

${ }^{20}$ Semra Genç, "Putin Döneminde Rusya'nın Ortadoğu Politikası ve Yeni Avrasyacılık", Akademik Araştırmalar Dergisi 37, (2008): 8.
} 


\section{Rus Basınında Arap Baharı}

küresel ölçekte büyük devlet/güç imajına zarar vereceğini düşünmüştür. $\mathrm{Bu}$ yaklaşım, Rusya'nın Suriye krizindeki siyasetini tayin eden unsurların başında gelmektedir.

Rusya'nın Arap Baharı sonrası Suriye siyasetinin belirlenmesinde yaşanan sürecin Rusya’nın ulusal güvenliği için bir tehdit olarak algılanmasının da payı vardır. Rusya, Arap Baharı ile birlikte Ortadoğu'nun genelinde, fakat bilhassa Suriye'de, muhtelif İslamcı grupların etkinliğinin artmasının ve bunların iktidara sahip olma arzusu içinde olmalarının ezelden beri yumuşak karnı olarak telakki ettiği Kuzey Kafkasya ile Volga/ İdil boyunda yaşayan Müslüman nüfusu arasında dini radikal ve terör yönelimleri çoğaltacağından endişe duymuştur. ${ }^{21}$

Rusya Federasyonu'nun Arap Baharı'na bağlı süreçlerle ilgili resmi çizgisi tutarlı ve tarafsız bir görünüm sergilemiştir. Daha evvel bahsi geçen hususlar dikkate alındığında, Rusya yönetimi Tunus, Mısır ve Libya'daki hadiselere yönelik oldukça pragmatik bir siyaset benimsemiştir ve iktidara gelen İslamcı kuvvetlerle ilişkiler tesis etmeye yönelmiştir. ${ }^{22}$ $\mathrm{Bu}$ çerçevede, Moskova tarafından iki hususa önem verilmiştir: İktidara gelenlerin ılımlı İslamcı olması ve bunların Rusya'nın iç işlerine yönelik söylemlerinin bulunmaması. Vladimir Putin, 2012'de dış politikayla ilgili kaleme aldığı yazısında, Rusya'nın ılımlı İslam'ın temsilcileriyle evvelden beri iyi münasebetler içinde olduğunu ve bu grupların dünya görüşlerinin Rusya Müslümanlarına yakın olduğunu vurgulamıştır. Ayrıca Rusya’nın, olayların vuku bulduğu devletler dâhil bütün Arap devletleriyle siyasi ve ekonomik münasebetlerini geliştirmek istediğini belirtmiştir. ${ }^{23}$

\footnotetext{
${ }^{21}$ Stanislav Mahnyov, “Ugrozı konflikta v Sirii dla natsionalnoy bezopasnosti RF," Vestnik Nijrgorodskogo universiteta im. N.I. Lobaçevskogo 1, sayı: 2, (2014): 347.

22 İlinıh, "Arabskaya vesna i rossiyskaya politika na Arabskom Vostoke v novıh usloviyah," 106.

${ }^{23}$ Vladimir Putin, “Rossiya i menyayuşiysya mir,” Moskovskiye Novosti, 27 Şubat 2012.
} 


\section{Ibragim KHASANOV}

Arap Baharı'nın Suriye'ye yayılmasıyla birlikte bu ülkeye atfedilen önem kendini göstermiş ve Rusya yönetiminde Suriye'de iktidar değişiminin ABD hegemonyasına hizmet edeceği, Kafkasya ve Orta Asya'yı doğrudan tehdit edeceği söylemleri yükselmiştir.

\section{Kritik Olaylar ve Ülkeler Bazında Rus Basınında Arap Baharı}

\section{Tunus}

Arap Baharı olayları diğer ülkelerde olduğu gibi Rusya'da da geniş yankı bulmuştur. Başlangıçta Rusya Federasyonu, devlet düzeyinde bu olaylara temkinli yaklaşıp ölçülü tepkiler vermekle yetinmiştir. Fakat bu ülkenin basını için aynı düzeyde bir reaksiyonun söz konusu olmadığı

Üsküdar University Journal of Social Sciences, 2020; issue: 10 , 93-128 belirtilmelidir. Konunun boyutları göz önünde bulundurulduğunda, Arap Baharı sürecinin Rus basınında yankıları, daha liberal ve eleştirel çizgiye sahip oldukları söylenebilen Vedomosti ile Kommersant gazeteleriyle, daha devletçi ve resmi çizgiye yakın olan Rossiyskaya gazeta ile Gazeta.ru gazeteleri çerçevesinde ele alınacaktır.

Tunus'taki olaylara Vedomosti gazetesinde "darbe" ve "renkli devrim" başlıkları altında yer verilmiştir. Ülkedeki gösterilerin ve kargaşanın yüksek düzeyli işsizlik ile gıda ürünlerindeki yüksek fiyatlara bağlı olarak siyasal iktidara karşı bir hoşnutsuzluk olarak ortaya çıktığı ifade edilmiştir..$^{24}$ Ayrıca olayların ülkenin batısında ekonomik taleplerle başlamasına rağmen kısa süre içerisinde başkente kadar yayılarak siyasal görünüme büründüğü kaydedilmiştir. Yazılarda gösterilerin itici gücünün üniversite öğrencileri ile orta sınıf olduğu bilgisi de yer almıştır. ${ }^{25}$

Tunus olayları ile ilgili aynı gazetede yer alan diğer yazılarda, bu ülkedeki olayların Rusya'daki durum ile bir mukayesesinin yapıldı̆̆ı dikkat

\footnotetext{
${ }^{24}$ Dmitriy Dmitriyenko, "V Tunise proizoşel gosudarstvennıy perevorot," Vedomosti, 14 Ocak 2011.

${ }^{25}$ Dmitriy Dmitriyenko, “Tsvetnaya revolutsiya v Tunise,” Vedomosti, 15 Ocak 2011.
} 


\section{Rus Basınında Arap Baharı}

çekmektedir. "Rusya için Tunus Dersi”, “Tunus'ta Devrimin Hafta Sonu” ve “Rusya için Tunus Senaryosu?” başlıklı yazılar bu hususta öne çıkmaktadır. Yazılarda Tunus'un bahsi geçen dönemde ortalama \%5'lik bir büyüme oranına sahip olduğundan, nüfusunun ücretsiz ve Fransız standartlarına yakın bir eğitim almış olduğundan bahsedilmiş ve bu ülkedeki gösterilerin çıkış noktasının, ekonomik durumdan ziyade ülkeyi 23 yıldır yöneten Bin Ali rejimi olduğunun altı çizilmiştir. Ayrıca Bin Ali'nin Belarus lideri Lukaşenko ile Venezüella eski lideri Hugo Chavez gibi, anayasadan devlet başkanının görev süresi ilgili maddeleri çıkardığı ve kendi klanının ülke ekonomisinin önde gelen sektörlerini ele geçirdiği dile getirilerek, dolaylı olarak Rusya yönetimi hedef alınmıştır. ${ }^{26}$ Diğer taraftan, Lenin'in devrim öncesi durumu tanımladığı üç esasa dayalı formüle atıfta bulunularak Tunus olaylarının Rusya'da vuku bulma ihtimali değerlendirilmiştir. Bu doğrultuda; Tunus'ta diplomalı işsiz gençlerin ayaklanmayı başlattığı, uzun süredir yönetimi işgal edenlerin süreci idare edemediği ve ülkenin ekonomik durumunun insan kitlelerinin etkinliğini artırdığı belirtilerek, Rusya’nın sahip olduğu ekonomik, siyasi göstergelerin devam etmesi halinde, 2017'de Lenin'in formülünün devreye gireceği ve Rusya'nın da Tunus'la benzer süreci yaşayacağı öngörüsünde bulunulmuştur. ${ }^{27}$ Benzer bir öngörünün paylaşıldığı diğer yazılarda ise Tunus senaryosunun Rusya'da tekrarlanmaması için ülkenin demokratikleşmesi gerektiği çağrısı yer almıştır. ${ }^{28}$

Tunus'taki olaylar çerçevesinde Kommersant gazetesinde yazılanlar, muhtevası itibariyle Vedomosti gazetesinde yazılanlarla paralellik sergilemektedir. Buradaki yazılarda Tunus'taki olayların itici gücünün

\footnotetext{
26 “Tunisskiy urok dla Rossii,” Vedomosti, 17 Ocak 2011.

${ }^{27}$ Dmitriy İvanov, “Revolutsionnıy uikend v Tunise: k probleme 2017,” Vedomosti, 18 Ocak 2011.

${ }^{28}$ Boris Makarenko, “Tunisskiy stsenariy dla Rossii?” Vedomosti, 20 Ocak 2011.
}

Üsküdar Üniversitesi Sosyal Bilimler Dergisi, 2020; sayl: 10 , 93-128 


\section{Ibragim KHASANOV}

üniversiteli genç kesim olduğu ${ }^{29}$ ve Tunus gibi dayanıklı bir rejime sahip olan bir ülkede bu tür olayların yaşanmasının Arap Dünyası için nadir bir vaka olduğunun üzerinde durulmuştur. ${ }^{30}$ Ayrıca Arapların "ayaklanmasının" gerçekleşmesinin çok zor bir olgu olmasına rağmen Tunus'ta 23 yıldır ülkeyi yöneten lidere karşı başlamasının beklenmedik bir nitelik taşıdığı belirtilmiştir. İlave olarak Cumhurbaşkanı Bin Ali’nin her şeye rağmen "kanlı bir tiran" olmamasının Tunus halkının "sabrının taşmasına" engel olamadığı ifade edilerek, insan ömrünün Tunus'a oranla 10 yıl daha kısa olduğu hatırlatmasıyla, benzer olayların Rusya'da da yaşanabileceği vurgulanmıştır. ${ }^{31}$

Tunus'taki olaylarla ilgili daha devletçi ve resmi çizgide olan Rossiyskaya

Üsküdar

University

Journal of Social Sciences, 2020; issue: 10 , 93-128 gazeta ile Gazeta.ru gazetelerine bakıldığında, bu kaynaklarda bahsi geçen Arap ülkesinde meydana gelen hadiselerin daha çok sonuçları üzerinde durulduğu görülmektedir. Rossiyskaya gazeta'daki yazılarda, esasen Tunus'taki olayların sonuçları ile Kafkasya ile Orta Asya'ya olası etkileri tartışılmıştır. Tunus'taki olayların arkasında ABD önderliğindeki Batı’nın olmadığı ve yaşananların bahsi geçen ülkenin iç dinamiklerine bağlı olarak geliştiği ve bunun da Batı’yı hazırlıksız yakaladığı belirtilmiştir. Ayrıca Tunus örneğinden yola çıkarak; devrimlerin nepotizm, rüşvet ve işsizlik gibi sorunları çözmediği, tam tersine, devrimler sonucunda bir "diktatörlüğün yerini başka bir diktatörlük" alarak toplumların daha kötü bir durumla karşı karşıya kalacakları vurgulanmıştır. ${ }^{32}$ Yine bu gazetede, olayların Kafkasya ile Orta Asya üzerindeki olası etkilerinde durulmuştur. Bu etkinin Tunus'taki devrimin orta vadedeki sonucuna

\footnotetext{
29 "Karfagen mojet bit razruşen," Kommersant, 12 Ocak 2011.

${ }^{30}$ Dmitriy Bondarenko, "Situatsiya dostatoçno redkaya dla arabskogo mira," Kommersant, 15 Ocak 2011.

${ }^{31}$ Stanislav Kuçer, “Terpeniye - prekrasnoye kaçestvo, no jizn slişkom korotka, çtobı terpet," Kommersant, 26 Ocak 2011.

${ }^{32}$ Andranik Migranyan, “Vzrıvı nazrevali iznutri,” Rossiyskaya gazeta, 10 Mart 2011.
} 


\section{Rus Basınında Arap Baharı}

bağlı olduğu belirtilmiştir. Olayların kaos ve iç savaşla sonuçlanmasının Tunus'ta radikal İslamcı grupların kuvvetlenmesine yol açarak bu ülkeyi uluslararası terörizmin merkezlerinden biri haline getireceği ve bunun Kafkasya ile Orta Asya'yı doğrudan tehdit edeceği kaydedilmiştir. Buna ilaveten, Batı́nın Tunus'taki olayları İslam dünyasının demokratikleşmesi çerçevesinde değerlendirdiği ve bu sürecin Orta Asya'ya da yayılmasını arzuladığ 1 düşüncesine yer verilmiştir.

Gazeta.ru'da yer alan yazılarda Tunus'la birlikte bölgede siyasal İslam'in etkinliğinin artması olasılığından duyulan rahatsızlık ön plana çıkmıştır. Yazıların birinde, Ortadoğu'da otoriter yönetimlerin muhalif güçler üzerindeki etkisinden ötürü demokratik biçimde yapılacak seçimlerden başarıyla çıkabilecek tek kuvvetin İslamcı partiler olduğu belirtilmiştir. Tunus özelinde İslamcı kuvvetlerin, ülkenin eğitim, bilim ve basın ile ilgili hükümet pozisyonlarını ele geçirmelerinin nahoş bir durum yaratarak Tunus'un Pakistanlılaşması sürecini başlatacağı ifade edilmiştir. ${ }^{33}$ Diğer yandan, Tunus'ta 2011'de devrim sonrası yapılan seçimlerin sonucuna atıfta bulunularak, İslamcıların bu ülkede elde ettikleri zaferin Kuzey Afrika'nın son 20 yılında bir ilk olduğu ve bunun "laik Tunus'un” sonu anlamına geldiği öne sürülmüştür. $\mathrm{Bu}$ gelişmenin diğer Ortadoğu ülkelerinde de yaşanacağını fakat iktidara gelecek olanların Tunus'takiler gibi "ilımlı" olmayacağının altı çizilmiştir. ${ }^{34}$

\section{MIsIr}

Mısır'da baş gösteren olaylar için Vedomosti gazetesindeki haberlerde Tunus'taki olaylarla bir paralellik kurulmuştur. Bu hususta, Mısır'daki göstericilerin Tunus'taki gibi ekonomik durumun iyileştirilmesini ve siyasal özgürlüklerin verilmesini isteyen gençler olduğu ifade edilmiştir. ${ }^{35}$

\footnotetext{
${ }^{33}$ Sergey Smirnov, “Nikogo, krome islamistov, net," Gazeta.ru, 21 Ekim 2011.

${ }^{34}$ Sergey Smirnov, "İslamistı pobedili," Gazeta.ru, 25 Ekim 2011.

35 “Vlasti Egipta v svyazi s besporyadkami blokirovali Twitter i Facebook," Vedomosti, 26
} 


\section{Ibragim KHASANOV}

Bununla birlikte, Hüsnü Mübarek'in tecrübeli bir siyasetçi olduğu hatırlatılarak, ülkede karışıklı̆̆ çözebileceği ihtimali dile getirilmiştir. Olası bir iktidar değişikliğinde ise Mübarek'e alternatif olabilecek "reel bir gücün liberal El Baradey'in” aksine İslamcı bir hareket olan Müslüman Kardeşler'in olduğuna dikkat çekilmiştir. ${ }^{36}$

Mısır'daki olaylar Kommersant gazetesinde de geniş yankı bulmuştur. Yazılarda, Mısır'ın Arap Dünyası için önemine dikkat çekilerek bu ülkede vuku bulan olayların bölgede domino etkisi yaratabileceği kaydedilmiştir. Ayrıca Arap Dünyası'ndaki bu süreçlerde esas itici gücün, genç kitleler yerine otoriter yönetimler tarafından geçmişte baskı altında tutulmuş İslamcı güçlerin olacağı öngörülmüştür. ${ }^{37}$ Benzer görüşe göre, Mısır'daki

Üsküdar University Journal of Social Sciences, 2020; issue: 10 , 93-128 olaylar 1917'de Rusya'daki sosyalist devrimle 1979 İran'daki İslam Devrimi'yle mukayese edilerek başlangıçta demokratik görünüme sahip devrimlerin, daha sonra uzun ömürlü totaliter rejimler doğurduğu saptaması yapılmıştır. Bu saptamada Ortadoğu'da istikrarı sağlayanların diktatörlükler olduğu vurgulanarak Mısır ile birlikte iktidara gelecek "İslamcı demokrasilerin" bölgeye rejim ve terör ihraç etmek isteyeceği belirtilmiştir. ${ }^{38}$

Rossiyskaya gazeta'daki Mısır'daki olaylarla ilgili yazılanlara bakıldığında ise hadiselerin asıl olarak ekonomik nedenlerden kaynaklandığı ve olaylarda belirgin olmamakla birlikte İslamcıların bu süreçlerden en çok kazançla çıkacak kesim olduğu görüşü yer almıştır. ${ }^{39}$

Gazeta.ru'da Rossiyskaya gazeta'nın aksine, Misır'daki olaylardan ordunun kazançlı çıkacağı görüşü yer bulmuştur. Bu çerçevede, ABD’nin,

Ocak 2011.

36 Dmitriy Dmitriyenko, "Protestı v Egipte prodoljilis posle otstavki pravitelstva," Vedomosti, 29 Ocak 2011.

37 “Egipet rasşatal piramidu vlasti," Kommersant, 31 Ocak 2011.

${ }^{38}$ Vladimir Beyder, “Arabskoye domino," Kommersant, 7 Şubat 2011.

${ }^{39}$ Evgeniy Primakov, “Voprosı prosnuvşihsya piramid,” Rossiyskaya gazeta, 31 Ocak 2011. 


\section{Rus Basınında Arap Baharı}

demokratik seçimler sonucunda İslamcıların iktidara geleceğini tahmin ettiği için Mübarek'in devrilmesine göz yumup Misır ordusunun iktidarı ele geçirmesini sağlayacağı ifade edilmiştir. Böyle bir iktidar değişikliğinin Ortadoğu için yeni bir model teşkil edebileceği ve bu modelin de XX. yüzyılda "Kemalist Türkiye'de" olduğu gibi ordunun "laik rejimin garantörü” rolünü üstlenmesiyle birlikte hayata geçebileceği vurgulanmıştır. ${ }^{40}$

\section{Libya}

Arap Baharı çerçevesinde Libya'da baş gösteren olaylar Şubat 2011'de başlamış ve kısa sürede ülkenin lideri Kaddafi ile göstericiler arasında şiddetli bir çatışma haline almıştır. Kısa bir süre sonra BMGK’nin ilgili kararına dayanarak uluslararası koalisyon güçleri Libya'daki çatışmalara göstericiler tarafında müdahil olmuş ve Kaddafi'nin iktidarına son verilmiştir. Libya'da yönetimin değişmesine rağmen ülke bugün fiilen ikiye bölünmüş bir vaziyettedir ve halen istikrar tesis edilememiştir. Libya'nın önemli bir petrol ihraç eden ülke olması ve ülkede vuku bulan olayların şiddet derecesinin yüksekliği buradaki olaylara uluslararası medya tarafından geniş yer verilmesine yol açmıştır. Rus basını için de aynı şey söz konusu olmuştur.

Bu doğrultuda Vedomosti gazetesinde Libya'daki olaylarla ilgili yapılan analizlerde iki boyut üzerinde durulduğu görülmektedir. İlkin, olayların Rusya için doğuracağı ekonomik sonuçlar değerlendirilmiştir. Bu hususta Libya'daki vaziyetin kontrol edilemez bir hal aldığı vurgulanarak bunun sonucunda Rus şirketlerinin bu ülkeyle yapmış olduğu yüksek meblağlı sözleşmelerin tehlikeye girdiği belirtilmiştir. ${ }^{41}$ Bununla birlikte, Libya ve Ortadoğu bölgesinin genelinde Arap Baharı süreciyle artan istikrarsızlı̆̆ın

\footnotetext{
${ }^{40}$ Fyodor Lukyanov, “Ataturk dla XXI veka,” Gazeta.ru, 3 Şubat 2011.

${ }^{41}$ Polina Himşiaşvili ve Aleksey Nikolskiy, “Ne do orujiya,” Vedomosti, 22 Şubat 2011.
} 


\section{Ibragim KHASANOV}

ardından bu bölgeye yapılacak olan yatırımların Rusya gibi ülkelere yönelebileceğine dikkat çekilmiştir. ${ }^{42}$ Vedomosti gazetesinde yapılan analizlerin ikinci boyutu bahsi geçen ülkedeki olaylara ABD ile Rusya'nın yaklaşımlarıyla ilgilidir. Bu çerçevede ABD’nin Libya siyasetinin amacının, Kaddafi'yi iktidarı bırakmaya zorlayarak Arap dünyasına ve genel olarak dünyaya ABD'nin Ortadoğu'da nüfuzunu muhafaza etmeye devam ettiğini göstermek ve dünyadaki hegemon güç konumunu kuvvetlendirmek olduğu öne sürülmüştür. ${ }^{43}$ Rusya'nın yaklaşımıyla ilgili ise bu ülkenin Kaddafi yönetimine yönelik yapmış olduğu kınayıcı açıklamalar ve $A B$ ile aynı safta yer alıyor gibi görünmesine rağmen Libya'daki durumun yönetimin lehine değişmesi halinde tutumunu değiştirebileceği iddia edilmiştir. ${ }^{4}$

Üsküdar

University

Journal of Social Sciences, 2020; issue: 10 , 93-128

Vedomosti gazetesine oranla Libya'daki olaylar Kommersant gazetesinde daha geniş bir çerçevede ele alınmıştır. Bahsi geçen gazetede olayların ekonomik etkileri, uluslararası arenada meydana getirdiği tepkiler, yaklaşımlar ve sonuçlar değerlendirilmiştir. $\mathrm{Bu}$ doğrultuda, Libya'da durumun Kaddafi yönetimi aleyhinde bir seyir izlemeye başlamasının bu ülkede iş yapan Rus şirketlerini belirsizliğe sürüklediği ifade edilmiş ${ }^{45}$ ve Batı devletleri başta olmak üzere uluslararası toplumun Libya olaylarına yaklaşımı değerlendirilmiştir. $\mathrm{Bu}$ minvalde, Kaddafi'nin Libya halkına yönelik öteden beri sert uygulamalarda bulunduğu hatırlatılarak Batı’nın 2011'e kadar bu yönetime karşı sert bir tutum içinde olmayışının nedeni sorgulanmıştır. ${ }^{46}$

42 Darya Borisyak, Margarita Lutova ve Ekaterina Kravçenko, “Udar po kapitalu," Vedomosti, 11 Mart 2011.

${ }^{43}$ Varvara Poludina, “Liviya napominayet Yugoslaviyu,” Vedomosti, 1 Mart 2011.

${ }^{44}$ Polina Himşiaşvili, "Politiçeskiy trup,” Vedomosti, 2 Mart 2011.

45 Aleksandr Gabuyev ve Aleksandr Pançenko, "Muamara Kaddafi valyat iz stranı," Kommersant, 22 Şubat 2011.

${ }^{46}$ Vladimir Beyder, “Tyajelaya forma nesmenyamosti,” Kommersant, 28 Şubat 2011. 


\section{Rus Basınında Arap Baharı}

Yine Kommersant gazetesinde Libya'daki olaylardan yola çıarak Ortadoğu'daki Arap Baharı sürecinin Çin Halk Cumhuriyeti üzerindeki etkisine yer verilmiştir. Bu hususta, Pekin yönetiminin ülkede Arap Baharı'na benzer hükümet karşıı gösterilen ayaklanmaların baş göstermesinden tedirginlik duyduğu ve buna karşı internet üzerinde devlet kontrolünü artırarak, özel kuvvetlerini güçlendirerek ve halkı sokağa çıkaracak sorunların çözümüne odaklanarak bir dizi önlemler almaya başladığı belirtilmiştir. ${ }^{47}$

Libya'ya askeri müdahale sonrası Arap Baharı'nın Ortadoğu'da meydana getirdiği sonuçlar Kommersant gazetesinde Arap Baharı'ndan "İslam Kışına” geçiş olarak nitelendirilmiştir. Bu minvalde, Libya'da Kaddafi'nin öldürülmesinin Ortadoğu'da Arap Baharı'nın yaşadığı bu dönüşümü yansıttığı ve bölgede iktidarın "laik ve kanlı" yöneticilerden "dini ve kanlı" yöneticilere geçtiği kaydedilmiştir.48 Aynı gazetede dikkat çeken bir diğer analiz ise Libya özelinde Arap Baharı́nın Rus diş politikasına etkisiyle ilgilidir. Bu hususta, Rusya'nın BMGK'de Libya'ya askeri müdahalenin önünü açan kararı veto etmeyerek ilk defa egemen bir devlerin iç işlerine askeri müdahaleye karşı çıkmadığı ifade edilerek, bunun ekseriyetle Rusya'nın Ortadoğu'dan çekildiği, dış politikasında önceliği yakın çevresine verdiği ve en önemlisi küresel bir süper güçten bölgesel bir güce dönüşüyor olduğu anlamına geldiği vurgulanmıştır. ${ }^{49}$

Rossiyskaya gazeta'ya bakıldığında, yazılarda ve analizlerde Libya'daki olayların mahiyetiyle ilgili bir tartışmanın yapılmış olduğu görülmektedir. Bir taraftan, olayların Libya gibi yoksulluğun olmadığı, hükümetin halka uygun barınma, eğitim ve sağlık hizmetleri sunduğu, gayri safi yurt içi hasılanın (GSYİH) Rusya'dan bile fazla olduğu petrol zengini bir ülkede

\footnotetext{
${ }^{47}$ Aleksandr Gabuyev, "Kitay zakrıvayet revolutsiyu na profilaktiku," Kommersant, 25 Şubat 2011.

${ }^{48}$ Kirill Pryaniçkin, “Epoha velikih sverjeniy,” Kommersant, 31 Ekim 2011.

${ }^{49}$ Fyodor Lukyanov, “Osen arabskoy vesnı,” Kommersant, 31 Ekim 2011.
}

Üsküdar

Üniversitesi

Sosyal Bilimler

Dergisi, 2020;

sayl: 10 ,

93-128 


\section{Ibragim KHASANOV}

genç nüfusun artan işsizlik, rüşvet ve kanunsuzluk gibi iç faktörlerden dolayı ayaklandığıifade edilmiş ${ }^{50}$, diğer taraftan da olayların karmaşı $1 k$ doğası itibarryla kesin olarak "turuncu" mu yoksa "yeşil” bir devrim mi olduğunun belirlenmesinin güç olduğu belirtilmiştir. ${ }^{51}$ Olayların mahiyetiyle ilgili dikkat çeken bir diğer husus da Libya ile birlikte Ortadoğu’da yaşanan Arap Baharı sürecinin Soğuk Savaş esasına dayanan eski dünya düzeninin yerine yenisinin oluşmakta olduğunu gösterdiği görüşüdür. Buna göre, Libya meselesi özelinde dünyanın büyük devletlerinin sergilediği ortak tutum, ${ }^{52}$ uluslararası alanda yeni dünya düzeninin esaslarının ortaya çlkmakta olduğuna işaret etmiştir..$^{53}$

Gazeta.ru gazetesinde ekseriyetle Libya'daki olaylar bağlamında Rusya’nınOrtadoğupolitikasınayönelikdeğerlendirmeleröneçıkmaktadır.

Üsküdar

University Journal of Social Sciences, 2020; issue: 10 , 93-128 $\mathrm{Bu}$ çerçevede, Rusyánın Libya'daki olaylarda bir yandan Kaddafi'yi kınayan, diğer yandan da bu ülkede yönetimin değişmesi durumunda Rus şirketlerinin ekonomik zarar edeceğine dair açıklamalarının Sovyetler Birliği'nin dağılmasından sonra Rusya’nın Ortadoğu’ya yönelik tutarlı bir siyaset üretemediğiniyansıtttı̆̆ı savunulmuştur. ${ }^{54}$ Ayrıca Rusya Federasyonu parlamentosunun alt kanadı Devlet Duma'sında yapılan tartışmalarda, dönemin Devlet Başkanı Medvedev ile Başbakan Putin arasında Libya'daki ihtilafa dair ortaya çıkan görüş ayrilğııın, milletvekilleri tarafından Rusya'nın Ortadoğu politikasına yönelik eleştirilerde bulunmalarına yol açtığı kaydedilmiştir. ${ }^{55}$ Yine bu minvalde yapılan bir değerlendirmede Libya politikası yüzünden Rusya’nın bu ülkeyle yapmış olduğu ekonomik

\footnotetext{
${ }^{50}$ Aleksandr Vasilyev, “Bitva ne za kusok hleba,” Rossiyskaya gazeta, 28 Şubat 2011.

${ }^{51}$ Mihail Margelov, “Velikaya Arabskaya revolutsiya,” Rossiyskaya gazeta, 1 Mart 2011.

52 BMGK'de Rusya ve Çin'in Libya'ya askeri müdahalenin önünü açan kararı veto etmemeleri kastedilmektedir.

${ }^{53}$ Nikolay Zlobin, “Konets yaltinskoy sistemı," Rossiyskaya gazeta, 9 Mart 2011.

${ }^{54}$ Gumer İsayev, “Na meste Livii i İraka obrazuyutsya çernıye dırı,” Gazeta.ru, 24 Mart 2011.

${ }^{55}$ Ekaterina Vinokurova, “Ni NATO, ni Livii," Gazeta.ru, 23 Mart 2011.
} 


\section{Rus Basınında Arap Baharı}

değeri yüksek anlaşmaları kaybettiğinin, askeri müdahale konusunda saf dışı bırakıldığının altı çizilmiş ve Rusya'nın Libya siyaseti “tam bir fiyasko” olarak nitelendirilmiştir. ${ }^{56}$

Gazeta.ru gazetesinde dikkat çeken bir diğer husus da Libya'daki olayların sonuçlarıylailgidir. Bu doğrultudaüçnoktaüzerinde durulmuştur. Birincisi, askeri müdahale konularında üyeleri arasında görüş birliği bulunmayan NATO'nun nasıl kullanılabileceği tecrübe edilmiştir. İkincisi, resmi amacı farklı olmasına rağmen Kaddafi'nin devrilmesi için kullanılan kararın BMGK’yi kararlarının meşruiyetini azaltmış olmasıdır. Üçüncüsü de Libya krizinin uluslararası politikada bölgesel teşkilatların ehemmiyetini artırdığını göstermiş olmasıdır. Bu görüşe göre, Arap Birliği’nin Kaddafi aleyhinde tutum alması, Rusya ve Çin'i Batı devletleriyle birlikte hareket etmeye yönelten önemli faktörlerden biridir. ${ }^{57}$

\section{Yemen}

Vedomosti gazetesinde Yemen'deki krizi konu alan yazılarda demokrasi çağrısı ön plana çıkmaktadır. Bu minvalde, adil ve demokratik seçimlerin, yöneticilerin halk tarafından desteklenmesinin ülkelerin gelişimi için yadsınamaz olduğu vurgulanarak Rusya'nın Yemen ve Arap Baharı'nın yaşandığı diğer ülkelerin hatalarını tekrarlamaması gerektiği belirtilmiştir. ${ }^{58}$ Yine bu doğrultuda, Yemen'de dönemin Cumhurbaşkanı Salih'in görevi kendi isteğiyle bıraktığı ifade edilerek uzun süre iktidara sahip olanların ülkelerinde çatışmaların, iç savaşların yaşanmaması için doğru zamanda görevi bırakmaları gerektiğinin altı çizilmiştir..$^{59}$ Burada, bariz bir şekilde olmamakla birlikte, Rusya'daki yönetim sisteminin durumuna işaret edilmiş olduğu ifade edilebilir.

\footnotetext{
${ }^{56}$ Georgiy Bovt, “Besporyadoçnaya interventsiya,” Gazeta.ru, 21 Mart 2011.

${ }^{57}$ Fyodor Lukyanov, “Devalvatsiya legitimnosti,” Gazeta.ru, 27 Ekim 2011.

${ }^{58}$ Konstantin Sonin, "Viborı kak instrument upravleniya," Vedomosti, 30 Ocak 2012.

59 “Diktatoru luçşe ne zaderjivatsya," Vedomosti, 22 Ocak 2012.
}

Üsküdar

Üniversitesi

Sosyal Bilimler Dergisi, 2020;

sayl: 10 , $93-128$ 


\section{Ibragim KHASANOV}

Kommersant gazetesine bakıldığında, Yemen krizine Batılı devletlerin yaklaşımının ele alındığı görülmektedir. Bahsi geçen gazetede Batılı devletlerin İran'daki gösterilerde muhalifleri desteklemesinin, Bahreyn'deki olaylara kayıtsız kalmasına karşın Yemen örneğinde ülkenin cumhurbaşkanının tarafında yer alarak faklı tutum sergilemiş olduklarının altı çizilmiş ve bunu da Yemen'deki olayların Suudi Arabistan’a yayılmasını önlemek, Kızıldeniz'de ve Bab'ül Mendep Boğazı'nda seyrüsefer rejiminin aksamamasını sağlamak için yapmış olduklarına dikkat çekilmiştir.60 Yine bu minvalde, Batılı devletlerin Yemen'de muhaliflerden yana olmayan tutumunun bilhassa Avrupa'nin daha evvel Tunus ve Misır'daki devrimler sonucunda karşı karşıya kaldığı göçmen/sı̆̆ınmacı akımının

Üsküdar University Journal of Social Sciences, 2020; issue: 10 , 93-128 tekrarlanmasını ve olayların Arap yarımadasına yayılarak petrol fiyatlarını yükseltmesini istemiyor olmalarına bağlı olduğu belirtilmiştir. ${ }^{61}$

Rossiyskaya gazeta'daki haber ve analizlerde, Yemen'e Körfez ülkelerinin askeri müdahalesine ve bu gelişmenin doğurduğu sonuçlara dikkat çekilmiştir. Gazetede Yemen Cumhurbaşkanı'nın talebi üzerine Suudi Arabistan liderliğindeki Körfez Arap Ülkeleri İşbirliği Konseyi'nin bu ülkeye askeri harekât kararı almış olduğu belirtilmiş ${ }^{62}$ ve bu gelişmenin Şii Husiler'i destekleyen İran'ın tepkisine yol açarak P5+1 görüşmeleri çerçevesinde imzalanması planlanan nükleer anlaşmanın geleceğini tehlikeye sokacağı görüşüne yer verilmiştir. ${ }^{63}$

Gazeta.ru gazetesinde Yemen'deki kriz, meseleye İran faktörü dahil edilerek bir analize tabi tutulmuştur. Bu çerçevede, Yemen'deki krizle

\footnotetext{
${ }^{60}$ Nikolay Zubov, “Totalnaya voyna dvortsam,” Kommersant, 21 Şubat 2011.

${ }^{61}$ Aleksandr Reutov, "U prezidenta Yemena naşlis storonniki," Kommersant, 16 Şubat 2011.

62 "Desyat stran naçali voennuyu operatsiyu v stolitse Yemena," Rossiyskaya gazeta, 26 Mart 2015.

${ }^{63}$ Vladislav Vorobyev, "Voyna v Yemene mojet sorvat peregovorı po yadernoy programme İrana,” Rossiyskaya gazeta, 26 Mart 2015.
} 
birlikte Ortadoğu'da şiddeti artan İran Suudi Arabistan rekabetinin/ mücadelesinin Orta çağı andıran bir mezhep savaşına dönüşebilme olasılığ 1 üzerinde durulmuştur. ${ }^{64}$ Bununla birlikte, Yemen üzerindeki İranSuudi Arabistan rekabetinin Rusya’nın Ortadoğu politikasına yönelik etkilerine de dikkat çekilmiştir. Bu hususta, Moskova'nın Tahran'la yakın ilişkilere sahip olmasına karşın, Ortadoğu'daki statükonun bu ülkenin lehine değişmesini arzu etmediği iddia edilmiştir. Bu görüşe göre, Rusya bir yandan İran'la yakın ilişkilerini muhafaza etmeye gayret gösterirken, diğer yandan da Yemen meselesinde Suudi Arabistan liderliğindeki koalisyonun eylemlerini fiilen destekleyerek Ortadoğu'daki Arap devletleriyle ilişkilerini sürdürmek istemektedir. Bu savı desteklemesi açısından, Rusya'nın Mısır ile yaptığı silah satış anlaşmaları örnek olarak gösterilmiştir. Bu bağlamda, Mısır'ın silah ithalatının Suudi Arabistan'ın vereceği krediye bağlı olduğunun farkında olan Rusya'nın Yemen meselesinde Riyad'la karşı karşıya gelmekten kaçındığı öne sürülmüştür. ${ }^{65}$

\section{Suriye Krizi Özelinde Rus Basınında Arap Baharı}

\section{Askerî Müdahale Kararından Önce}

Ortadoğu'da yaşanan Arap Baharı sürecinin bir devamı olarak nitelendirilen ve 2011'de Suriye'de patlak veren olaylar kısa sürede halen çözüme kavuşturulamamış, bölgesel ve bölge-dışı aktörlerin aktif olarak yer aldığı bir iç savaş halini almıştır. Rusya Federasyonu yönetiminin Suriye meselesi özelinde Arap Baharı’nın yaşandığı diğer ülkelerde takip ettiği siyasi çizgiden farklı bir yaklaşım içerisine girmesi, bu ülkedeki olaylara Rus basınında daha geniş yer verilmesini de beraberinde getirmiştir.

\footnotetext{
64 “Mı vozvraşayemsya v Srednedekovye," Gazeta.ru, 3 Ocak 2016.

${ }^{65}$ Aleksandr Braterskiy, "Saudovskiye bombı byut po rossiyskim pozitsiyam," Gazeta.ru, 27 Mart 2015.
} 


\section{Ibragim KHASANOV}

Vedomosti gazetesinde Rusya’nın Suriye'deki olaylara yaklaşımı genel olarak sert bir eleştiriye tabi tutulmuştur. Bahsi geçen gazetede yer alan yazılarda Suriye’ye silah ihracatını sürdürebilmek için Rusya'nın “binlerce insanın ölümünden sorumlu olan” Şam yönetimini desteklemeyi sürdürmesi ve uluslararası düzeyde bu ülkeye yönelik yaptırımların uygulanmasına engel olması bariz bir şekilde kınanmıştır.66 Yine bu minvaldeki yazılarda, Rusya'nın Esad rejimini desteklemesinin bu ülkedeki "katliamları artırdığı" vurgulanarak, Rusya'nın benimsediği yaklaşımın nedenlerine dikkat çekilmiştir. Buna göre, Rusya Suriye’yi önemli bir silah pazarı olarak görmekle birlikte, bu ülkedeki rejim değişikliğinin ileride İran'la beraber kendisini de tehdit edeceğini düşünmekte olduğu

Üsküdar University Journal of Social Sciences, 2020; issue: 10 , 93-128 görüşüne yer verilmiştir. ${ }^{67}$

Kommersant gazetesinde, Rusya'nın Suriye'deki olaylara yaklaşımının yanı sıra, genel olarak, Rusya’nın Ortadoğu politikasına yönelik tenkitler öne çıkmaktadır. Bu doğrultuda, Rusya'nın XX. yüzyılda takip ettiği Ortadoğu politikası dönemin şartlarına atıfta bulunularak haklıgörülmekle birlikte, ülkenin Soğuk Savaş sonrası bölgeye yönelik dış siyasetinde bir "tutarsızlık” olduğuna dikkat çekilmiştir. Rusya'nın, Kaddafi'ye karşı uluslararası müdahaleye göz yumarken Esad söz konusu olduğunda aynı şeyi yapmaması, Hamas'ı meşru bir siyasi güç olarak kabul ederken İran'daki muhalefete aynı şekilde yaklaşmaması ve İsrail'le iyi ilişkiler tesis edilirken diğer yandan da bu ülkenin düşmanlarına silah satılması, Kommersant gazetesindeki yazılarda Rusya'nın Ortadoğu'daki süreçleri "yeterince anlayamaması" ve bölgeye yönelik çıkarlarını tanımlayamaması olarak telakki edilmiştir. Bu çerçevede, yazılarda, Rusya'nın Suriye'de

\footnotetext{
${ }^{66}$ Polina Himşiaşvili ve Aleksey Nikolskiy, "Poçti dve tısyaçi jertv ne zastavili Rossiyu podderjat sanktsii protiv Sirii,” Vedomosti, 2 Ağustos 2011.

67 “Siriyskiy tupik," Vedomosti, 16 Kasım 2011.
} 


\section{Rus Basınında Arap Baharı}

"başarısızlığa mahkûm olan eli kanlı bir diktatörü" desteklemesi sorgulanmıştır. ${ }^{68}$

Bahsi geçen bu iki gazeteden farklı olarak, Rossiyskaya gazeta'daki yazılar ve analizlerde, Rusya'nın Suriye özelinde izlediği politikaya destek verildiği görülmektedir. Bu hususta Rusya'nın “Ortadoğu'daki dengeleri değiştirme arzusunda olan” Batılı devletlerin aksine Suriye’de Libya senaryosunun yaşanmaması için çaba gösterdiğine ${ }^{69}$ ve Esad yönetiminin devrilmesi sonucunda ülkede iç savaşın yanı sıra Sünnilerle Şiiler arasında mezhep savaşının çıkacağına ve Türkiye ile Ürdün'ün Suriye topraklarına yönelik genişleme girişimlerinde bulunacaklarına dikkat çekilmiştir.70 Ayrıca Batı́nın Suriye'ye askeri müdahale niyetinde olduğu bir dönemde Moskova'nın diplomatik girişimlerle yetinmesinin Rusya için "jeopolitik bir yenilgi” olacağı üzerinde durularak Rusya’nın stratejik müttefik olarak nitelendirdiği Suriye Hükümeti'nin yanında olmasının ve bunun için gerekirse kuvvet kullanmasının haklı olduğunun altı önemle çizilmiştir. ${ }^{71}$

Gazeta.ru gazetesinde, Rusya'nın Suriye politikasına olumlu yaklaşılmakla birlikte Moskova'nın bu ülkede daha sert politikalar izlemesi gerektiği savunulmuştur. Bu çerçevede, Rusya ile Batı arasında yürütülen müzakere sürecinin bir sonuç vermeyeceği, Annan Planı başta olmak üzere uluslararası çözüm girişimlerinin başarı ihtimali olmadığı üzerinde durularak Rusya'nın Suriye'deki iç savaşa doğrudan askeri müdahalede bulunarak ihtilafın taraflarını barışa zorlaması gerektiği belirtilmiştir. ${ }^{72}$ Bahsi geçen gazetede dikkat çeken bir diğer husus da Suriye krizinin

\footnotetext{
68 “Moskva pitaetsya vnov igrat na blijnevostoçnoy şahmatnoy doske," Kommersant, 10 Haziran 2011.

${ }^{69}$ Vladislav Vorobyev, “Asadnoye polojeniye,” Rossiyskaya gazeta, 22 Haziran 2011.

${ }^{70}$ Vladislav Vorobyev, "Sirii pomogayut poyti po liviyskomu stsenariyu," Rossiyskaya gazeta, 24 Kasim 2011.

${ }^{71}$ Evgeniy Şestakov, “Rossiya ne doljna sdavat Siriyu,” Rossiyskaya gazeta, 27 Kasım 2011.

${ }^{72}$ Georgiy Bovt, "V zaşitu despota," Gazeta.ru, 4 Haziran 2012.
}

Üsküdar Üniversitesi Sosyal Bilimler Dergisi, 2020; sayl: 10 , 93-128 


\section{Ibragim KHASANOV}

Rusya’nın uluslararası arenadaki konumuna olan etkisiyle ilgilidir. $\mathrm{Bu}$ doğrultudaki yazılarda, Rusya’nın Suriye krizi özelinde izlediği siyasetin amacının Batı ve Arap Dünyası'na Ortadoğu başta olmak üzere dünyanın herhangi bir yerinde bir meselenin Rusya'ya rağmen çözülemeyeceğini göstermek olduğu ve bunu yapmakta da Rusyánın muvaffak olduğu kaydedilmiştir. ${ }^{73}$

\section{Askerî Müdahale Kararından Sonra}

Rusya’nın 30 Eylül 2015'te aldığ Suriye'ye askeri müdahale kararı, Vedomosti gazetesi yazı ve analizlerinde destek bulmamıştır. Bu doğrultuda yapılan analizlerde, Rusya'nın Suriye'de askeri operasyonlara katılmasının

Üsküdar University Journal of Social Sciences, 2020; issue: 10 , 93-128 bu ülkedeki terör unsurlarının Rusya'yı da hedef alması, ${ }^{74}$ Rusya'nın Esad karşıtı Körfez ülkeleriyle ticari, ekonomik ve askeri alanlarda işbirliği projelerinin iptal edilmesi ve Moskova’nın Batı karşıtı güçlerin elinde bir "araca" dönüşmesi gibi sonuçlar doğurabileceği üzerinde durulmuştur. ${ }^{75}$ Ayrıca, Kremlin yönetiminin, ülkede ekonomik sıkıntıların ve Ukrayna'nın doğusunda krizin devam ettiği bir dönemde böyle bir karar almasının iç politikada gündemi değiştirme çabası olduğu görüşüne yer verilmiştir. ${ }^{76}$ Vedomosti gazetesinde dikkat çeken bir diğer husus da Sovyetler Birliği'nin 1979'da başlayan Afganistan müdahalesine atıfta bulunularak, Suriye'deki operasyonlar sonucunda Rusya'nın, Afganistan'da olduğu gibi can kaybından öteye bir şey elde edemeyeceği kanaatidir.77

Kommersant gazetesinde, Rusya'nın Suriye'de operasyonlara katılma kararı daha çok ekonomik düzlemde analize tabi tutulmuştur. Bahsi geçen

\footnotetext{
${ }^{73}$ Fyodor Lukyanov, “Ekzamen po Sirii,” Gazeta.ru, 5 Nisan 2012.

${ }^{74}$ Denis Sokolov, “Negibridnaya voyna,” Vedomosti, 6 Ekim 2015.

${ }^{75}$ Maksim Trudolyubov ve Pavel Aptekar, "Kak Rossiya stala aviatsiyey Başara Asada," Vedomosti, 8 Ekim 2015.

${ }^{76}$ Nikolay Epple, “Komu voyna, a komu slava,” Vedomosti, 1 Ekim 2015.

${ }^{77}$ Leonid İsayev, “Rossiya rasşiryayet siriyskiy tupik,” Vedomosti, 30 Eylül 2015.
} 


\section{Rus Basınında Arap Baharı}

kararın, Rusya’nın Türkiye’yle olan başta Türk Akımı ve Akkuyu nükleer enerji santrali gibi projeleri kapsayan enerji alanındaki iş birliğine zarar verebileceği ${ }^{78}$, Ukrayna'dakikrizle birlikte uluslararası kuruluşlar tarafindan Rusya'nın dış yatırımlar ve turizm alanları için notunun düşürülmesine yol açtığ $1^{79}$ ve operasyonların amacının ve süresinin yönetim tarafından net olarak belirlenmediği için Rusya'ya, bu kararın ekonomik maliyetinin elde edeceği siyasi kazanımlardan daha fazla olacağı iddia edilmiştir..$^{80}$

Rossiyskaya gazeta'da konuyla ilgili yayınlarda, devletin resmi çizgisinin yansitıldığı görülmektedir. Rusya Federasyonu resmi makamlarının yaptığı Rusya Silahlı Kuvvetleri'nin Suriye'de yalnız hava operasyonlarına katılacağı, operasyonların amacının IŞi̇D ile mücadele olduğu ve Suriye Devlet Başkanı Esad'ın talebi üzerine Rusya'nın aldığı bu kararın uluslararası hukuka uygun olduğu yönündeki açıllamalara bahsi geçen gazetede geniş yer verilmiştir. ${ }^{81}$ Bununla birlikte, Kremlin'nin Suriye kararının Sovyetler Birliği’nin dağılmasından sonra ilk defa Batı'yı Rusya'yla müzakere masasına oturmak zorunda bıraktığına ${ }^{82}$ ve "Rus ordusunun gerçekte nelere kadir olduğunu” gösterdiğine önemle dikkat çekilmiştir. ${ }^{83}$

Gazeta.ru'da yer alan değerlendirmelerde, Rusya'nın Suriye'de askeri harekata katılması meşru görülmekle birlikte bu hususta birtakım hassasiyetler dile getirilmiştir. Bunlara göre, Rusya’nın Suriye'deki savaşa doğrudan müdahil olması, Ukrayna'daki savaşta yer almasından

${ }^{78}$ Yuriy Barsukov ve Olga Kuznetsova, “Turtsiya metit pryamo v gaz, Kommersant, 9 Ekim 2015.

${ }^{79}$ Yana Paşaeva, “Mı ne opustilis na uroven Zimbabve," Kommersant, 14 Ekim 2015.

${ }^{80}$ Aleksandr Konovalov ve İvan Safronov, "Skladıvayetsya vpeçatleniye, çto toçnoy summı na operatsiyu v Sirii poka net," Kommersant, 12 Ekim 2015.

${ }^{81}$ Tatyana Zamahina, “Uprejdayuşiy udar,” Rossiyskaya gazeta, 30 Eylül 2015.

${ }^{82}$ Evgeniy Şestakov, “Venskoye derjavyu,” Rossiyskaya gazeta, 20 Ekim 2015.

${ }^{83}$ Anton Valagin, "Rossiyskaya asimmetriya vnov şokirovala SŞA," Rossiyskaya gazeta, 20 Ekim 2015. 


\section{Ibragim KHASANOV}

daha mühimdir. Rusyảnın Suriye cephesinde yenilgiye uğraması Batı ve İslam Dünyası'nın elini kuvvetlendirecek olduğundan Rusya Suriye'den muhakkak zaferle ayrılmalıdır. ${ }^{84}$ Rusya'nın Suriye'de askeri müdahale kararı almasının, bahsi geçen gazetede, Rus dış politikasında bir dönüşüme işaret ettiği görüşüne de yer verilmiştir. Bu çerçevede, Kırım ve Donbass'taki hadiselerden sonra Moskova'nın "Rus Dünyası'nı bir araya getirme" politikasından vazgeçerek uluslararası alanda daha mühim meselelere yoğunlaştığı (Suriye, IŞiD ile mücadele kastedilerek) ifade edilmektedir. Rus dış politikasında bu olgu, "Rus milliyetçiliğinden emperyalizme geçiş" olarak adlandırılmıştır. ${ }^{85}$

Üsküdar University Journal of Social Sciences, 2020; issue: 10 , 93-128

\section{Sonuç}

Tunus, Misir, Libya, Yemen ve Suriye'de Arap Baharı́na bağlı olarak vuku bulan gelişmeler Rus basınında geniş bir çerçevede ele alınmıştır. Devam eden Suriye krizi ise halen Rus basınında gündemi oluşturan en mühim konuların başında gelmektedir. Arap Baharı olayları, uzmanların bir bölümü tarafindan ABD’nin Büyük Ortadoğu Projesi çerçevesinde bölgeyi şekillendirme girişime olarak telakki edilmiştir. Çalışma kapsamında yazıları ve analizleri incelenen Vedomosti, Kommersant, Rossiyskaya gazeta ve Gazeta.ru gazetelerinde bu görüşün benimsenmemiş olduğu görülmüştür. Rus basınında Arap Baharı olaylarında ABD’nin tutumunun/yaklaşımının önemine dikkat çekilmiş olmasına rağmen olayların ortaya çıma nedeni olarak Arap devletlerinin iç dinamiklerine işaret edilmiştir.

Ayrıca incelenen gazetelerin manşetlerinde radikal İslam, İslamcı gruplar başlıklarının \%4 oranından daha az olduğu tespit edilmiştir. Buna karşın, Tunus veMısır olaylariç̧in bahsigeçen dörtgazetenin manş̧etlerinde darbe, renkli devrim, hükümet karşıı gösteriler, olayların diğer ülkelere

84 “Na Asadnom polojeniyi," Gazeta.ru, 30 Eylül 2015.

${ }^{85}$ Semyon Novoprudskiy, “İmperializm pobedil,” Gazeta.ru, 30 Ekim 2015. 
yayılma olasılığını ifade eden domino etkisi gibi tabirler kullanılmıştır. Libya olayları için ise, gelişmelerin bu ülkedeki Rus şirketlerine olası ekonomik maliyetlerine işaret eden sermaye, Kaddafi kastedilerek, "siyasi ceset", büyük darbeler dönemi ve "Büyük Arap Devrimi” gibi tabirler tercih edilmiştir. Yemen krizinde Rus basınının bahsi geçen gazetelerinde seçimler, diktatörlük, saraylara karşı savaş, askeri operasyon ve İran ile nükleer anlaşma gibi başlıklar/manşetler öne çıkmıştır. Rusya’nın devlet olarak en fazla önem verdiği ve doğrudan müdahil olduğu Suriye krizi ise Rus basınında yaptırımlar, Suriye çıkmazı, Ortadoğu satranç tahtası, Libya senaryosu, Suriye sınavı, Türkiye’yle ilişkiler, operasyonların maliyeti gibi tabirler kullanılarak manşetlere taşınmıştır.

Arap Baharı́nın yaşandı̆g i ülkeler arasında yapılan bu çalışma kapsamında, Rusya'da gerek devlet düzeyinde gerekse basında gündemi meşgul etmesi, Rusya’nın ve iç ve dış politikasını doğrudan ilgilendirmesi gibi hususlara bağlı olarak Suriye’nin/Suriye krizinin öne çıktığı saptanmıştır.

\section{KAYNAKÇA}

Barsukov, Yuriy ve Olga Kuznetsova. "Turtsiya metit pryamo v gaz." Kommersant, 9 Ekim 2015.

Beyder, Vladimir. “Arabskoye domino.” Kommersant, 7 Şubat 2011.

Beyder, Vladimir. “Tyajelaya forma nesmenyamosti.” Kommersant, 28 Şubat 2011.

Bondarenko, Dmitriy. "Situatsiya dostatoçno redkaya dla arabskogo mira." Kommersant, 15 Ocak 2011.

Borisyak, Darya, Margarita Lutova ve Ekaterina Kravçenko. "Udar po kapitalu." Vedomosti, 11 Mart 2011.

Bovt, Georgiy. “Besporyadoçnaya interventsiya.” Gazeta.ru, 21 Mart 2011. 


\section{Ibragim KHASANOV}

Bovt, Georgiy. "V zaşitu despota.” Gazeta.ru, 4 Haziran 2012.

Braterskiy, Aleksandr. "Saudovskiye bombı byut po rossiyskim pozitsiyam.” Gazeta.ru, 27 Mart 2015.

Çiftçi, Kemal. "Ulus-Devletlerden Kozmopolitan Küreselleşmeye Uluslararası Siyaseti Yeniden İnşa Etmek: Arap Baharı Örneği.” Karadeniz Sosyal Bilimler Dergisi 7, sayı: 13, (2015): 179-207.

Demçenko, Aleksandr. “«Arabskaya vesna» i politika Rossii v blijnevostoçnom regione.” Perspektivy, (2012). Erişim 18 Aralık 2018. http://www.perspektivy.info/rus/desk/arabskaja_vesna_i_politika rossii_v_blizhnevostochnom_regione_2012-09-15.htm

Üsküdar University Journal of Social Sciences, 2020; issue: 10 , 93-128

"Desyat stran naçali voennuyu operatsiyu v stolitse Yemena." Rossiyskaya gazeta, 26 Mart 2015.

“Diktatoru luçşe ne zaderjivatsya.” Vedomosti, 22 Ocak 2012.

Dmitriyenko, Dmitriy. "Protestı v Egipte prodoljilis posle otstavki pravitelstva." Vedomosti, 29 Ocak 2011.

Dmitriyenko, Dmitriy. “Tsvetnaya revolutsiya v Tunise.” Vedomosti, 15 Ocak 2011.

Dmitriyenko, Dmitriy. "V Tunise proizoşel gosudarstvennıy perevorot." Vedomosti, 14 Ocak 2011.

“Egipet rasşatal piramidu vlasti." Kommersant, 31 Ocak 2011.

Epple, Nikolay. “Komu voyna, a komu slava.” Vedomosti, 1 Ekim 2015.

Erşen, Emre. “Rusya’nın Arap Baharı Politikası.” Arap Baharı Üzerine Değerlendirmeler içinde, Editörler: Armağan Gözkaman, Perihan Paksoy, 115-135. Ankara: Detay Yayıncilık, 2014.

Gabuyev, Aleksandr ve Aleksandr Pançenko. "Muamara Kaddafi valyat iz stranı.” Kommersant, 22 Şubat 2011. 


\section{Rus Basınında Arap Baharı}

Gabuyev, Aleksandr. "Kitay zakrivayet revolutsiyu na profilaktiku." Kommersant, 25 Şubat 2011.

Genç, Semra. "Putin Döneminde Rusya'nın Ortadoğu Politikası ve Yeni Avrasyacılık." Akademik Araştırmalar Dergisi 37, (2008): 1-19.

Giniyatov, Farit. “Sobıtiya arabskoy vesnı i ih vliyaniye na geopolitiçeskoye polojeniye Rossii v blijnevostoçnom regione.” Vestnik ekonomiki prava i sotsiologii 2, (2013): 134-136.

Himşiaşvili, Polina ve Aleksey Nikolskiy. "Ne do orujiya." Vedomosti, 22 Şubat 2011.

Himşiaşvili, Polina ve Aleksey Nikolskiy. "Poçti dve tısyaçi jertv ne zastavili Rossiyu podderjat sanktsii protiv Sirii.” Vedomosti, 2 Ağustos 2011.

Himşiaşvili, Polina. “Politiçeskiy trup.” Vedomosti, 2 Mart 2011.

İlinıh, Aleksandr. "Arabskaya vesna i rossiyskaya politika na Arabskom Vostoke v novıh usloviyah.” İstoriko-pedagogiçeskiye çteniya 17, (2013): 101-108.

İsayev, Gumer. "Na meste Livii i İraka obrazuyutsya çernıye dırı." Gazeta. ru, 24 Mart 2011.

İsayev, Leonid, "Rossiya rasşiryayet siriyskiy tupik.” Vedomosti, 30 Eylül 2015.

İvanov, Dmitriy. "Revolutsionniy uikend v Tunise: k probleme 2017." Vedomosti, 18 Ocak 2011.

“Karfagen mojet bit razruşen.” Kommersant, 12 Ocak 2011.

Kemaloğlu, İlyas. Rusya'nın Ortadoğu Politikası. Ankara: ORSAM, 2012.

Konovalov, Aleksandr ve İvan Safronov. "Skladıvayetsya vpeçatleniye, çto toçnoy summı na operatsiyu v Sirii poka net." Kommersant, 12 Ekim 2015.

Kuçer, Stanislav. "Terpeniye - prekrasnoye kaçestvo, no jizn slişkom korotka, çtobı terpet.” Kommersant, 26 Ocak 2011. 


\section{Ibragim KHASANOV}

Lukyanov, Fyodor. “Ekzamen po Sirii.” Gazeta.ru, 5 Nisan 2012.

Lukyanov, Fyodor. “Osen arabskoy vesnı." Kommersant, 31 Ekim 2011.

Lukyanov, Fyodor. “Ataturk dla XXI veka.” Gazeta.ru, 3 Şubat 2011.

Lukyanov, Fyodor. “Devalvatsiya legitimnosti.” Gazeta.ru, 27 Ekim 2011.

Mahnyov, Stanislav. "Ugrozı konflikta v Sirii dla natsionalnoy bezopasnosti RF.” Vestnik Nijrgorodskogo universiteta im. N.İ. Lobaçevskogo 1, sayı: 2, (2014): 345-350.

Makarenko, Boris. “Tunisskiy stsenariy dla Rossii?” Vedomosti, 20 Ocak 2011.

Margelov, Mihail. "Velikaya Arabskaya revolutsiya." Rossiyskaya gazeta, 1

Üsküdar

University

Journal of Social Sciences, 2020; issue: 10 , 93-128 Mart 2011.

“Mı vozvraşayemsya v Srednedekovye." Gazeta.ru, 3 Ocak 2016.

Migranyan, Andranik. "Vzrıvı nazrevali iznutri." Rossiyskaya gazeta, 10 Mart 2011.

"Moskva pitaetsya vnov igrat na blijnevostoçnoy şahmatnoy doske." Kommersant, 10 Haziran 2011.

“Na Asadnom polojeniyi.” Gazeta.ru, 30 Eylül 2015.

Nassasra, Yusef. "Strategiçeskiye prioritetı blijnevostoçnoy politiki Rossii v period posle arabskoy vesnı." Privoljskiy nauçnıy vestnik 12-1, sayı: 52, (2015): 129-133.

Novikov, Dmitriy. "Ritsar rossiyskogo realizma." Erişim 21 Nisan 2020. https://www.globalaffairs.ru/articles/ryczar-rossijskogo-realizma/

Novoprudskiy, Semyon. “İmperializm pobedil.” Gazeta.ru, 30 Ekim 2015. Paşayeva, Yana. "Mı ne opustilis na uroven Zimbabve." Kommersant, 14 Ekim 2015.

Poludina, Varvara. "Liviya napominayet Yugoslaviyu." Vedomosti, 1 Mart 2011. 
Rus Basınında Arap Baharı

Primakov, Evgeniy. "Voprosı prosnuvşihsya piramid.” Rossiyskaya gazeta, 31 Ocak 2011.

Pryaniçkin, Kirill. "Epoha velikih sverjeniy." Kommersant, 31 Ekim 2011.

Putin, Vladimir. “Rossiya i menyayuşiysya mir." Moskovskiye Novosti, 27 Şubat 2012.

Reutov, Aleksandr. "U prezidenta Yemena naşlis storonniki." Kommersant, 16 Şubat 2011.

RF Dışişleri Bakanlığı. "RF Dışişleri Bakanı S.Lavrov'un Kanal 3’te V.Solovyev’a verdiği röportaj.” Erişim 18 Aralık 2018. http://www.mid. $\mathrm{ru} /$ foreign_policy/news/-/asset_publisher/cKNonkJE02Bw/content/ $\mathrm{id} / 215526$

RF Dışişleri Bakanlığı. "RF Dışişleri Bakanlığı Sözcüsü A.K.Lukaşeviç’in Tunus'taki olaylara dair açıklaması.” Erişim 18 Aralık 2018. http://www. mid.ru/ru/press_service/spokesman/official_statement/-/asset publisher/t2GCdmD8RNIr/content/id/222358

RF Dışişleri Bakanlığı. "RF Dışişleri Bakanlığı Sözcüsü A.K.Lukaşeviç’in Mısır'daki olaylara dair açıllaması.” Erişim 18 Aralık 2018. http://www. mid.ru/ru/press_service/spokesman/official_statement/-/asset publisher/t2GCdmD8RNIr/content/id/219002

Sapronova, Marina. "Rossiysko-arabskoye sotrudniçestvo do i posle arabskoy vesnı.” Vestnik MGİMO Universiteta 3, sayı: 36, (2014): 27-36.

“Siriyskiy tupik.” Vedomosti, 16 Kasım 2011.

Smirnov, Sergey. “İslamistı pobedili.” Gazeta.ru, 25 Ekim 2011.

Smirnov, Sergey. "Nikogo, krome islamistov, net." Gazeta.ru, 21 Ekim 2011.

Sokolov, Denis. “Negibridnaya voyna.” Vedomosti, 6 Ekim 2015.

Sonin, Konstantin. "Viborı kak instrument upravleniya." Vedomosti, 30 Ocak 2012. 


\section{Ibragim KHASANOV}

Şestakov, Evgeniy. “Rossiya ne doljna sdavat Siriyu.” Rossiyskaya gazeta, 27 Kasim 2011.

Şestakov, Evgeniy. “Venskoye derjavyu.” Rossiyskaya gazeta, 20 Ekim 2015.

Trudolyubov, Maksim ve Pavel Aptekar. "Kak Rossiya stala aviatsiyey Başara Asada.” Vedomosti, 8 Ekim 2015.

“Tunisskiy urok dla Rossii.” Vedomosti, 17 Ocak 2011.

Valagin, Anton. "Rossiyskaya asimmetriya vnov şokirovala SŞA." Rossiyskaya gazeta, 20 Ekim 2015.

Vasilyev, Aleksandr. "Bitva ne za kusok hleba." Rossiyskaya gazeta, 28 Şubat 2011.

Üsküdar

University

Journal of Social Sciences, 2020; issue: 10 , 93-128
Vinokurova, Ekaterina. “Ni NATO, ni Livii.” Gazeta.ru, 23 Mart 2011.

"Vlasti Egipta v svyazi s besporyadkami blokirovali Twitter i Facebook." Vedomosti, 26 Ocak 2011.

Vorobyev, Vladislav. "Asadnoye polojeniye." Rossiyskaya gazeta, 22 Haziran 2011.

Vorobyev, Vladislav. "Sirii pomogayut poyti po liviyskomu stsenariyu." Rossiyskaya gazeta, 24 Kasim 2011.

Vorobyev, Vladislav. "Voyna v Yemene mojet sorvat peregovorı po yadernoy programme İrana.” Rossiyskaya gazeta, 26 Mart 2015.

Zamahina, Tatyana. "Uprejdayuşiy udar.” Rossiyskaya gazeta, 30 Eylül 2015 .

Zlobin, Nikolay. "Konets yaltinskoy sistemı." Rossiyskaya gazeta, 9 Mart 2011.

Zubov, Nikolay. “Totalnaya voyna dvortsam.” Kommersant, 21 Şubat 2011. 